\title{
Indigenous or Exotic? Trees in Australian Cinema
}

\author{
Chris Mann
}

James Cook University

\begin{abstract}
This article examines trees in three Australian films to assess if they are seen from a white point of view or an Indigenous point of view.

$\mathrm{I}$ n an article published in 1990, Anne Hickling-Hudson said of Nicolas Roeg's Walkabout that its focus was on "the story of the whites" (264) rather than on the story of the Aborigine (whose walkabout is overtaken by the needs of the two white children, who survive, whereas he does not). It is perhaps time, forty years after Walkabout, to see if there is still truth in this assertion. To check on any progression, three films will be discussed Bitter Springs (1950), Walkabout (1971) and Australia (2008). While it is acknowledged that there are more than three Australian films with trees in them, these three will give some indication of whether a change has occurred.
\end{abstract}

Trees have been chosen because they are an easily separable part of landscape and can be given a certain identity while still being part of what would normally be called the film's subtext which it is illuminating to study since it can reveal underlying attitudes to confirm or deny what appear to be the apparent messages of a film. In the three films chosen, trees are an important part of the location in which the story has been situated. In all three films location is itself important, as indeed it tends to be in Australian films situated primarily outside the city as these three are - location frequently has such hardships associated with it for white people in Australia that it could easily be considered as having a role as vital as any of the characters. On the surface, for example, The Overlanders and Red River are both talking about a cattle drive, but whereas in Red River the main conflicts occur between the John Wayne character and the Montgomery Clift one, in The Overlanders the struggle is almost always of the people against the land. It will be noted that the titles of two of the three films to be looked at are locations, and the third implies travel across them. As Luhrmann has said of Australia, "the location is a character in the movie" (Turk 23), and Nowra thinks that Roeg gave landscape the same prominence: "Roeg is one of the few filmmakers to understand that the Australian landscape is a character in its own right." (75)

An article by Lukinbeal notes that there are four ways landscape can be considered in a film: as "space", when it is just a background (6), as "place" when it is acknowledged as grounding or even contributing to the action (7), as "spectacle" when it is presented as "something fascinating in itself”, "a spectacle of beauty” or a generator of "curiosity and interest” (11), and as "metaphor", appropriating "meaning and ideology [...] into landscape" (13). "Metaphor" seems to be carrying the burden of all non-literal associations, and if one accepts it as that then that is primarily the way trees will be looked at in this article, although the giant baobab trees in Australia stretching themselves against vivid sunsets could obviously also be considered as spectacle and although in all three films, the trees carry metaphoric weight because they have been constituted as grounding or even contributing to the action, being part of this landscape which has the force of a character in films about Australia outside the city. 
That trees (or landscape in general) might be allowed a metaphorical life in film may seem questionable but there is no doubt they have sometimes been invested with metaphorical values outside film - evident for example in the Bible's Tree of Life and Tree of Knowledge - and there is no reason why this should not carry over into film. The film The Tree is in fact a recent example of this. The tree of The Tree becomes associated in the mind of a young child with the spirit of her father who died of a heart attack just as he was getting home and whose utility rolled to a stop against a large Moreton Bay fig growing close to the family house. That the child's hearing the tree as the voice of her father should not be dismissed by the audience as a piece of childish imagining is strongly suggested when the mother is considering establishing a relationship with another man and the tree loses a huge limb which comes down on the house, invading the bedroom with its branches and lying across part of the bed.

Jackie Hogan raises one further issue relevant to this article on trees. Speaking of Australia, she says in it "Aboriginal Australians [...] are Othered by virtue of their mystical powers and their primordial ties to Nature" and that Nullah and King George "are positioned as part of the natural realm, bound to the ancient past, and separated by their essential nature from the life of the Modern Australian nation” (68). In a film set primarily in the country, Aborigines might be said to have three choices: their traditional links to nature, no links to nature and new links to nature (eg as the owners of cattle stations). The three films considered do not present the third option. This article is taking the view that when one looks at nature in the films to establish their indigenous-centredness, traditional links to nature are preferable to no links to nature, the risk of being treated as a Romantic cliché being preferable to total dispossession.

In Bitter Springs, conflict arises between a group of white settlers who have been given a pastoral lease by the government of South Australia and the traditional owners, the Karragani tribe. To build a homestead, the settlers chop down trees. Several writers have pointed out that the film's sympathies lie with the tribe. Pike says: despite the hypocrisy of its ending [when the tribe having agreed to let the settlers stay, helps them shear sheep], the film is for the most part imbued with genuine concern for the plight of the Aborigines, and the white settlers are far from sympathetic characters (597)

and Verhoeven agrees (Sabine 149). However, it is not clear whether this concern is evident in the tree-chopping sequences. A section of episode 1 of Rachel Perkins' seven-part documentary First Australians talks about early white expansion into land beyond the Blue Mountains occupied by the Wiradjuri people. A narrator says:

The Wiradjuri watch as the land is cleared of trees. Trees have special meaning for the Wiradjuri, who carve into their bark to mark graveyards and sacred initiation sites they call bora grounds.

To which Bill Allen, a Wiradjuri descendant, adds: It's just a tree to other people, I think, whereas to us it's part of our being and this would have enraged the Wiradjuri people that they were knocking down these sacred objects that were part of their belief system.

While Larkins referring to Bitter Springs speaks of "a sacred Aboriginal waterhole” (67) and in the film the trooper Ransome says "the land's sacred to them”, little in the film suggests the trees cut down by the settlers were regarded as sacred by the Karragani. In one sequence in which the Scotsman Mac is cutting down a tree, he is watched by a member of the tribe, 
but the Karragani's expression shows curiosity rather than horror - Molloy says he watches "intently" (191) and despite the fact that Molloy also remarks that the tree felling is changing the environment (191), there is no evidence that that is how the watching Aborigine is judging the situation - , and Mac just smiles at him and then continues chopping. As Mac is also the member of the group who at other moments is the readiest to speak out for the rights of the tribe, we are unlikely to interpret his tree felling as unfriendly. Mac is also the carpenter: since he needs planks to make a house for the others, it is natural he should get himself some wood. In this scene, and in another scene where several others of the settlers fell trees and lop off the side branches, jolly music encourages them in their efforts. The film seems to be on the side of the fellers, sympathising with their need for timber and underlining the joy of a group endeavour. Evidence to the contrary is only circumstantial: the way the Karragani melt "at will into the trees and rocks" (Sabine 149), suggests they are at one with nature and would not want it harmed, but there is no attempt to stop the felling. The film as a whole seems to be opposing two geometries: the whites are straight-line people, journeying to their destination by filling in vast holes and digging themselves out of bogs, rather than go round anything. They kill their game by shooting it, the trajectory of the bullet being basically straight. The whites are direct in their declaration of intent to stay, and their first inclination is to be unyielding. The tribe on the other hand hunt with boomerangs or spears, both of which have a curved trajectory (as the neighbouring tribe's chief demonstrates by hitting a target on the other side of a large boulder with a spear), their plans to recapture the waterhole are based on encirclement and in their dealings with the whites they are prepared to negotiate. In this context of curves being seen positively, the chopping off of side branches and the rectangular alignment of the frame of the house under construction may be casting aspersions on the activity but this is very subtle criticism which can hardly counteract a smiling Scot going gaily about his business. It is true the Karragani end up burning down the homestead, but what has "enraged" them, as Bill Allen put it, is not the desecration of trees but the settlers' killing one of their number.

The writer who has discussed in greatest depth the trees of Walkabout is Izod. He considers principally trees at three moments of the film - when the two white children find a tree by an oasis before they meet the Aborigine on his walkabout, when the three of them play in a tree during their wanderings and when the Aborigine commits suicide in a tree towards the end of the film. Izod's comments are as follows:

This tree [at the oasis], obviously a life-giver, yet has important differences

from the biblical image. During the night a furry mammal visits the children, and a snake moves across the branches. Thus intimations of Edenic innocence mix with the idea of knowledge. [...] the principal association of this tree remains life; but it links life subtly with knowledge, ignorance and death. (114)

[In the scene of them playing, $t$ ]he camera reinforces the association of community, joy and sexuality by selecting angles on the branches which emphasise the likeness of swellings in the fork to the female genitals.

And then at the same time Roeg intercuts these shots unexpectedly with shots of aborigines exploring the father's burnt-out car and of his charred body, which has been stretched grotesquely in a dead tree. The tree motif again couples life and death in a mysterious conjunction whose potential is not fully articulated until the last appearance of the image near the end of the film. (114)

The last appearance of the image is discussed as follows by Izod: 
his body [the Aborigine's] hangs in a mango tree. The image of him recalls of course that of their father buried in a dead tree, and more esoterically that ancient emblem of Christ on the Cross, who from the Middle Ages to the seventeenth century could be emblematically represented as the loveliest fruit of the tree. (116)

There are several ways to consider whose trees these are. Izod is suggesting that the film is clearly marking them as belonging to Christian symbolism. While there are many Aborigines who would count themselves Christians and many Europeans who would reject Christianity, it is a faith which has been longer established in the West than among Aborigines. Burying people in trees is an Indigenous custom, but the Aborigine at the end hangs vertically with his arms outstretched like Christ on the Cross.

Another way to consider one of the trees, the one the children play in, is to examine whose sexuality it is expressing or commenting on. The comment is made by shots which compare the girl hanging upside down from a limb of the tree and trying to control her skirt since her position is revealing her underpants, to the near-naked Aborigines at the site of the father's burnt-out car who are playing and laughing unselfconsciously. The comment is therefore applying to both groups, though it has more pertinence for the girl since it is with her and her awkward sexuality that the story mainly deals.

It is after this crosscutting that the tree is used to express sexual thoughts, when the camera focusses on forks resembling female genitalia, as Izod says above, though without saying whose point of view is being expressed. Other commentators do, however. Geist thinks the limbs indicate "the guide’s dawning sexual interest in her" (66) and Gow agrees:

He gazes at the white limbs of a tree, seen by Roeg's camera as

erotic female shapes, which might be a rudimentary notion but is so

astutely placed as to radiate the feeling of the youth (54).

If Geist and Gow are right, then the Aborigine's viewpoint is being expressed. In my opinion this is unlikely. First at an earlier stage of the walk the angle of the view of the Aborigine's exposed butt is clearly the girl's, who is walking behind him, and when later the Aborigine expresses his feelings it is more indirectly and perhaps more chastely, by a dance with flowers. Second, the arrangement of the shots either side of the shots of the limbs suggest the person seeing the limbs is the girl: the Aborigine is lying down looking in her direction and says something to her in his language to which she replies, in English: “ They'll be all right in the morning", rubbing the inside of her sore thighs. She continues: "They got a bit sore from...”, whereupon she looks up at the tree and sees the suggestive shapes. The camera's gaze comes down from the tree and goes first to a close up of the Aborigine's face, but he is not looking up into the tree but rather still in the girl's direction. Then the camera turns to the girl who lowers her glance from the tree, sees the Aborigine and says "Oh dear". She imagines him as a sexual threat because of her lewd interpretation of his feelings, based on her own preoccupation with bodily modesty.

One further, minor, point in Walkabout concerns the first tree, at the oasis. Strange identifies it as a "quondong" (sic) (10). When the boy takes his first bite of one of its fruit, he says: "It tastes lovely." He then explains that "It tastes like meat", which is an unusual way for a white person to describe a fruit's taste. Perhaps the boy, who later turns out to be much more capable than his sister of relating to the Aborigine, is in fact being allowed by the script to echo an Indigenous viewpoint of this fruit, since one can read at one site about the quandong that “Amongst male members of central Australia's Pitjantjara people, Quandongs were 
considered a suitable substitute for meat” (“Quandongs”). It remains nonetheless true that the overarching interpretation of this oasis is linked to the initial innocence of the garden of Eden (as expressed here by the boy) followed by the expulsion of the children for misusing it (in particular for sullying its water). The trees in Walkabout mostly support Hickling-Hudson's view, that the film focusses on white concerns. ${ }^{1}$

Luhrmann's Australia is a more complex case. It opens and closes speaking of the Stolen Generation and an important story in the film is Nullah's, the child of the white man Fletcher and the Indigenous woman Daisy. His story resembles that of members of the stolen generation in two ways. The first is that he is looked after (unofficially) by two white people, Lady Sarah Ashley and Drover, after his mother is drowned and his father will not accept the responsibilities of his paternity. The second is that he is put into state custody in line with the 1930s' policy of assimilation. At the end of the film, Nullah is allowed to return to his biological grand-father King George, with whom he sets out on walkabout. Since Nullah ends up escaping from white management - and is also the narrator - it would seem Australia has focussed upon Indigenous interests and has given them an acceptably Indigenous solution.

Arguments against this view centre mainly on the film's story up to the ending, though the ending also has a problem, as will be discussed later. Kemp states that Daisy is drowned "so that Sarah can bond with the boy and discover her repressed maternal instincts” (48).

Luhrmann's director of photography, Mandy Walker, says that "When he talked to me about this movie it was always in terms of the emotional journey of Sarah Ashley” (Turk 23).

According to Papson, "The battle between good and evil is played out between Fletcher and Lady Ashley. This battle takes place across the body of Nullah”. He adds:

Whiteness works as the invisible hand of the film. The conflict between

Fletcher, the Drover and Sarah drives the plot. The Drover speaks for and about Indigenous peoples.

Hogan agrees with Papson's last remark:

I suggest that the film reiterates certain longstanding discourses of

Australian national identity by fetishising white Australian manhood and marginalising women and non-white Others. (63)

Bradshaw echoes these sentiments in commenting on Nullah's central role:

The grotesque condescension of making the only important Aborigine character a child would rather seem to underline the racists' repeated declarations that the Aborigines are just children.

What say the trees? The tree which is most visible in Australia - which, despite carrying the name of the whole country, is set almost entirely in Australia's tropical North is the baobab. Adansonia gregorii is at least native to Australia although other members of

\footnotetext{
${ }^{1}$ Brief mention may be made of two other readings of trees in Walkabout because they show that Izod's reading is not unique and because these other two interpretations (by Louis Nowra and Leonard Held) are also white-centred. For Nowra "the solitary quandong tree in the middle of the desert had the mysterious visual potency of a Byzantine icon" (5-6) and the snake in the tree evokes the garden of Eden (36). The final tree speaks of "The merciless cycle of life and death" because "the Aborigine hanged himself from a tree full of mangoes. The Girl picks up mangoes from the feet of a dead man because it will sustain herself and her brother" (59). Because it is possible the idea of life and death being in a cycle is as much Indigenous as white, the metaphoric value of the tree may be shared, though from the point of view of Lukinbeal's "place", Nowra's interpretation of the role of the tree in this scene clearly favours the whites: it is pleasanter to be picking mangoes on the life side of the cycle than hanging dead in the tree. Held's interpretation of Walkabout is based primarily on Jung's writings, in particular "The Philosophical Tree" (interwoven with further Christian imagery). For example, he refers to Jung's concept of the Cosmic Tree's links to "the two [Held does not consider the third, crucifixion, Tree] central trees in Walkabout: the Tree of Knowledge and the Tree of Life.” (24) He continues: “On another, but equally important level, is the significance of the Cosmic Tree in terms of its appearance in the unconscious.” (24-5) While everyone has an unconscious of some sort or other, this is an occidental reading of it.
} 
the genus are more numerous in Africa and Madagascar. It also can be linked to the Aborigines of the regions where it grows.

On 13 October 1837, George Grey, Captain of the $83^{\text {rd }}$ Regiment and later to be Governor of South Australia, set out for north-western Australia on a commission of exploration.

They [... ] recorded many wonders, including this [ a baobab, of which Grey says]: ' $[\ldots]$ its worth is well known to the natives, for its vicinity is one of their favourite haunts. Around nearly all of them I have found marks of their fires' (Sedden 46-7).

One reads elsewhere: "Aboriginals used the giants as shelter, food and medicine” ("The Boab Tree - Our Kimberley Icon.”). How long the baobab has been in Australia is uncertain, but even Sedden, who argues against the baobab having grown on Gondwana, seems not to contest David Baum's suggestion that it arrived, water-borne, about 30 million years ago (58).

The choice of the baobab by Luhrmann as Australia's principal tree does not then exclude the Indigenous inhabitants as the choice of an exotic might have, even if there is a certain stereotypical glibness in accompanying an ancient people with an ancient tree. How in fact are the Aborigines of the film associated with this tree? The founding image occurs right at the start of the film, when King George and Nullah are seen at dusk or dawn in silhouette beneath the branches of a baobab. Nullah says that he and King George are going on walkabout and that he is learning things from King George, in particular the importance of story. By this association the first baobab is marked out as Nullah's and King George's, and as a place where wisdom is transmitted. Admittedly such an association may more readily conjure up Buddha sitting beneath a banyan tree; admittedly also, this first scene has at the start written across it "September 1939", a date with more significance for white Australians with roots in England than for the Indigenous population - but nonetheless this first manifestation should be seen primarily as inclusive of Aborigines.

There are two main baobabs in Australia. The first one is the one just described. One cannot tell its location at the start because the camera does not leave the silhouette, but the silhouette of that particular tree does occur at other moments when it is situated in a precise spot. The baobab is in fact the one which stands just a little way outside the garden fence of the Faraway Downs homestead.

Whose is it then? There are four occurrences which are close visually to the opening shot with Nullah and King George. The first is at dusk on the day Daisy dies. Magarri lifts her body from the tray of a utility and then shouts up to King George (her father) who is on a high hill overlooking the property. He laments his dead daughter. Wood fires blaze to either side of the tree. The second is Christmas one year when all at Faraway Downs are outside at a dining table under the tree. The tree comes into its fully recognizable silhouette when Nullah says the word "Christmas". The third time the angle is different but it is dusk. Drover and Sarah are kissing in front of the baobab and gradually its image fades leaving just Drover and Sarah. The fourth time the angle is different too but the tree is forming part of another composition at sunset: it is silhouetted to the left while Drover is on a horse with Sarah standing beside it. In other words, the tree's closest Indigenous association is sombre (Daisy's death); in the other scenes it is a background to white men's business, though it has a certain reflective tranquillity which links it back to its first appearance. 
The same baobab is visible during the day. The times it is close are all associated with Drover: when Lady Sarah first arrives at Faraway Downs with Drover and Flynn, fires are burning, probably in connection with the death of Maitland who is laid out in the homestead. Drover gets out of the truck and the camera is angled up at him through flames. He looks worried, and the baobab looming large behind him adds gravity to the scene. The two other times when the tree is in the foreground are definitely not reflective but rather busy white man's moments: these are when Drover comes back to the homestead in a tumult of brumbies and gallops past the trunk of the tree. Presumably he could hardly wheel his brumbies through the front garden and the baobab is the next best sign to the viewers that he is back.

The other scenes of the homestead in which the baobab is visible place it much further away and it may perhaps be assumed to be just part of the setting. Dramatic things are happening in the foreground like the arrival or departure of the police who are looking for Nullah, or the departure of a hostile Fletcher after Sarah has sacked him, but something dramatic is always happening in Australia. Nullah runs away through a spindly grove of baobabs and Sarah does her practice cattle rounding up in a bigger, much handsomer one, but let us move on to the other main baobab.

This is the baobab which is near water. It is not near the homestead and its silhouette is different from Nullah's and King George's. Whose tree is this? Like the first baobab in some of its appearances, it is a dusk or night tree, and has contemplative connections. It is at the centre of three scenes. The first time is on the second night after the day Flynn is trampled to death in the stampede. There is a fire going and the droving party toast the memory of Flynn with rum. If this baobab may be said to communicate with the other, we may note that the funeral has become a white one. After several tots of rum, Sarah is emboldened to invite Drover to dance, and in the course of their lurchings they end up against the tree, where they exchange their first kiss (the kisses associated with the first baobab occur later). One can hear Sing Song strumming on a banjo. The tender scene is interrupted by Nullah who unbeknown to the couple was up in the tree. He wants to know if they are intending to do "Wrong-side Business". Bandy Legs tells him to get down at once because there are "bad spirits" up in the tree, a warning neutralised and even ridiculed by Sing Song's incredulous expression. Sarah and Drover have the usual discussion following a first kiss where each, though particularly Drover, gives an account of their past love life. In a word, by the end of this scene this second baobab is the backdrop for a budding white love affair. ${ }^{2}$ (ii).

The second baobab's second appearance is at dusk. Drover and Magarri, his Indigenous brother-in-law from his first marriage, are doing an army drove. Magarri is humming "Over the Rainbow” as, in his role as subordinate, he lights a fire, while Drover places his hand on the trunk of the baobab. What Drover is thinking is revealed in the following exchange with Magarri:

\footnotetext{
${ }^{2}$ The association of the second baobab with love is reinforced later on after Drover and Sarah have spent their first night together: in ecstasy, the camera shoots off over the landscape in search of tumbling water, but on its way there it zooms past the second baobab. In connection with this link to love, one might wonder to what extent the mention of "Wrong-side Business" and a tree with evil spirits in it should be taken as a tasteless white subversion of an indigenous belief or just treated as a harmless joke. It rather depends on whether one can just take "Wrong-side Business" as a general euphemism for making love. If not, one may be in more sensitive territory, since early in Xavier Herbert's novel Poor Fellow My Country (with which Hergenhan and Conor affirm Australia has links), Jeremy Delacy explains that "To Aborigines, love's always a matter of law-breaking. You only fall in love with someone Wahji or Wrong-side to you" (24) and that the mangan, or native plum, is "supposed to have the power to attract and spellbind lovers, so that they may be crept up on and killed" (24).
} 


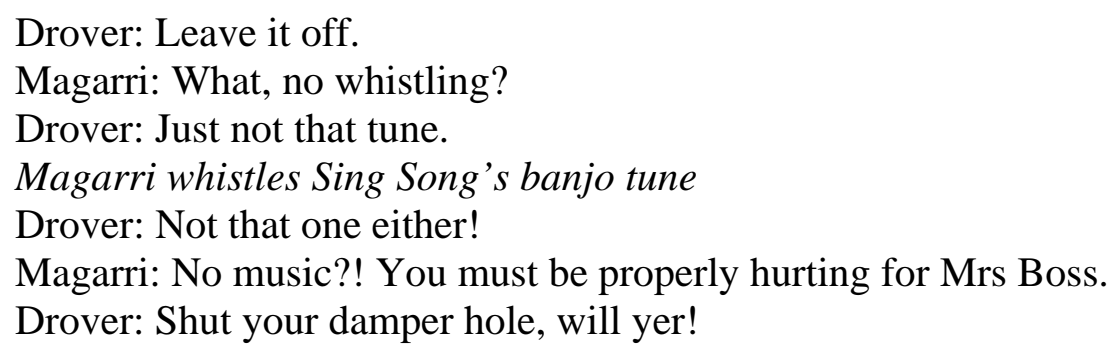

This conversation, already centred on Drover's lovesickness and conducted by him with a brusqueness that his aching heart only partially excuses, is further detached from its Indigenous surroundings by being also an allusion to Casablanca. The joke centres around two Casablanca scenes:

(a) In the restaurant at Rick's:

At Ilsa's request, Sam has started to sing “As time goes by".

Rick strides up.

Rick: Sam, I thought I told you never to play...

He catches sight of Ilsa.

(b) In the upper room at Rick's:

Rick is slumped over a table. Sam starts playing a tune on the piano.

Rick: What's that you're playing?

Sam: Oh, just a little something of my own.

Rick: Well stop it. You know what I want to hear.

Sam: No I don't.

Rick: You played it for her, you play it for me.

Sam: Well I don't think I can remember.

Rick: If she can stand it, I can. Play it!

Sam: Yes boss.

Sam begins to play "As time goes by”.

While there are dissimilarities between the two films, the similarities are striking:

- There is music being performed which hurts the protagonist because it is connected to an earlier love.

- A separation of lovers has occurred because of the Second World War.

- The time period is during the Second World War.

- The protagonist forbids (then, in Casablanca, requests) the performance of the tune.

- Twice the protagonist forbids tunes to be played.

- The source of the music is a black man who is the subordinate of the protagonist.

- The white man is brusque in his dealings with the black man.

- The black man obeys only reluctantly.

Luhrmann is having some fun, but it is not Indigenous fun and hardly innocent as it seems to reinforce Magarri's subordinate status.

The unpromising start to this scene from an Indigenous point of view does however turn around, because Magarri then attacks Drover based on Indigenous knowledge and values, for once undermining Drover as a fount of Indigenous wisdom. First he criticises Drover for allowing Nullah to go off on walkabout all on his own, seeing as naïve Drover's assumption that Nullah as an Aborigine should naturally go on walkabout. Magarri points out that Nullah is only a child and may very well have fallen into a hole, or been captured by "the cops". The force of what Magarri is asserting is strengthened for the spectator, who knows that Nullah 
has indeed been taken into custody. Magarri then attacks Drover for stubbornly refusing to acknowledge his love for Sarah and for not having declared his love to her: "You've got no love in your heart". The final, and, in the context of the start of the film, strongly Indigenous, criticism is that Drover has "No dreaming, no story". The baobab of the second half of the scene therefore is reclaimed as a tree of Indigenous wisdom, as the first baobab was at the start.

The final appearance of the second baobab is right at the end of the film. It is late afternoon and for some reason - there doesn't appear to be a drove on, so one may assume that the second baobab has accumulated some strong symbolic value by now - we are back at this tree. Gathered at the tree are Drover, Sarah and Nullah (King George is out on the savannah on one leg, gesturing to Nullah to come to him). Sarah and Nullah are together near the tree (which is in shot) and Sarah is about to let Nullah leave on walkabout. Nullah gives Sarah a hug, which, as she is standing, only goes round her waist. Because she is wearing a long brown skirt, her lower half looks like the trunk of a sturdy European sapling (we have been prepared for this rather unlikely image of Nicole Kidman as tree by the first baobab fading into her and Drover as referred to earlier). From his hug Nullah starts to move away from Sarah until they are just holding hands. At the very moment their hands part, Drover appears from behind the baobab and rests his hand on its trunk. Because Sarah is present, this touching does not have to be the lovelorn reminiscing associated with his touching the tree before. What this ballet of hands may rather be read as is that at the same time as Nullah rejects the European tree, Drover asserts the primacy of the baobab, returned to its proper state as a part of the Indigenous landscape. Nullah has helped place this scene in an Indigenous context by saying as they arrive there in the car: "One thing I know: why we tell story is the most important of all - that's how you keep them people belonging, always.” Another incidental - but positive from the Indigenous point of view, if not the feminist one sign is that it is Sarah, not Magarri, or Nullah, who is gathering wood to tend the fire.

The only element detracting from the Indigenousness of this scene is the music that plays right through it. Denby explains:

At the end, King George summons Nullah to a rite of passage, a walkabout. Nullah's disappearance into the desert, leaving the whites behind, is framed as a triumphant anti-colonial moment, but Luhrmann confuses the issue by accompanying the scene with, of all things, the stirring "Nimrod" passage from "Enigma Variations” by Edward Elgar, the composer perhaps most closely associated with the glories of empire.

Admittedly, Nimrod is the Hunter and hunting is probably what Nullah and King George are going off to do, but there must be other less imperially charged melodies about this pursuit.

If one may speak further of music, as the credits begin to roll, a female voice starts to sing "By the boab tree". ${ }^{3}$ (iii). Perhaps the song is being addressed to Nullah since it starts "Sing

\footnotetext{
${ }^{3}$ Here is the full text of the song given in "australiamovie", with what is actually sung over the credits underlined: Sing and I will hear you / No matter where you are /A song to light the darkest night /And guide me from afar/And I will never be alone / Now I know you're somewhere / You're everywhere to me / You're the colour in the sky /A reason to believe And when the rain falls down / You tell a story /And I will hear you /Always near you / By the boab tree / Lay your arms around me / Like the falling rain / Let the feeling drown me / And life begins again / And I will never be afraid / Now I know you're somewhere / You're everywhere to me / The warming of the sun upon / The earth beneath my feet / And when the rain falls down / You tell a story / And I will hear you / Always near you / By the boab tree / Oh you are somewhere / You're everywhere to me / You're the colour in the sky / And you're the earth beneath my feet / And when the rain falls down / You tell a story / And I will hear you / Always near you / By the boab tree.
} 
and I will hear you”, (Sarah has just said "And I will hear you” to Nullah as he leaves on walkabout) but this seems unlikely as Sarah would hardly add to him as the voice does in the song "And I will never be afraid / Now I know you're somewhere / You're everywhere to me / The warming of the sun upon / The earth beneath my feet [...]" The song is therefore probably using the "boab" and Nullah's favourite line about singing Sarah to him, in the service of a white love. But at least it only occurs with the credits, which no one sits through.

Although Australia goes some way towards using the landscape as a means of Indigenous expression, it certainly puts it to other uses as well, despite having Indigenous issues as one of its main themes. If one takes the idea of an Indigenous voice literally, there is only once in the film when an Indigenous person expresses herself unambiguously about the baobab, and that is when Bandy Legs talks about evil spirits, an opinion that another character quickly discounts. Moreover, even if one accepts what this article has affirmed about the indirect associations of the baobab with an Indigenous voice, Australia is still a film made by a white. However, as the majority of films are made by whites, it is necessary to be prepared to interrogate them.

Under such interrogation, Australia does respond better than either Bitter Springs or Walkabout. It may be part of a change of white consciousness after the High Court decision on terra nullius, a theme taken up by Felicity Collins and Therese Davis in their book Australian Cinema after Mabo.

Of course, for purposes of comparison, it would be useful to have an Indigenous film in which trees are treated metaphorically, but such a treatment does not exist in films such as Samson and Delilah or Bran Nue Dae, which is hardly surprising because trees in most films are usually part of what Lukinbeal calls "space" or "place", and one might expect films made by Indigenous directors to be less inclined to accept "Aborigines and romanticised nature" as one of their themes. Certainly both Samson and Delilah and Bran Nue Dae are focussed on social issues. Ten Canoes, a film made through initial collaboration between Rolf de Heer and David Gulpilil and with an Indigenous co-director, Peter Djiggir, from which whites are excluded, does have trees, but their treatment, in the black-and-white half of the film which deals with more recent times, is primarily matter-of-fact: the bark of trees is shown as having been harvested for canoes or trees were useful refuges when hunting for goose eggs.

\section{Works Cited}

Australia. Dir. Baz Luhrmann. 20th Century Fox, 2008. DVD.

<http://www.australiamovie.net/soundtrack-lyrics/\#boab> Web. 22 March 2012.

Bitter Springs. Dir. Ralph Smart. Ealing Studios, 1950. VHS.

“The Boab Tree - Our Kimberley Icon.” Web. 24 October 2011. < $\underline{\text { http://www.outback- }}$ australia-travel-secrets.com/boab_tree.html.>

Bradshaw, Peter. “Down blunder.” Web. 29 December 2008. <http://www.guardian.co.uk/film/2008/dec/22/baz-luhrmann-australia-film.> 
Bran Nue Dae. Dir. Rachel Perkins. Robyn Kershaw Productions, 2009. Film.

Casablanca. Dir. Michael Curtiz. Warner Bros, 1942. DVD.

Collins, Felicity and Therese Davis. Australian Cinema after Mabo. Cambridge: Cambridge University Press, 2004. Print.

Conor, Liz. "A 'nation so ill-begotten': racialized childhood and conceptions of national belonging in Xavier Herbert's Poor Fellow My Country and Baz Luhrmann's Australia.” Studies in Australasian Cinema 4.2 (2010): 97-113. Print.

Denby, David. “History in the Making.” Web. 6 January 2009.

$<$ http://find.galegroup.com/itx/retrieve.do?contentSet=IAC-Documen...>

First Australians. Dir. Rachel Perkins. Episode 1. SBS, 2007. DVD.

Geist, Kenneth. “Cinematic poem Down Under.” Village Voice May 20, 1971: 66. Print.

Gow, Gordon. “Walkabout.” Films and filming 18.3 (December 1971): 53-54. Print.

Held, Leonard. “Myth and Archetype in Nicolas Roeg’s Walkabout.” Post Script 5.3 (1986): 21-46. Print.

Herbert, Xavier. Poor Fellow My Country. Sydney and London: Collins, 1975. Print.

Hergenhan, Laurie. “Australia: Echoes of Xavier Herbert.” Quadrant 53.3 (March 2009): 16-18.

Print.

Hickling-Hudson, Anne. "White Construction of Black Identity in Australian Films about Aborigines.” Literature/Film Quarterly 18.4 (1990): 263-274. Print.

Hogan, Jackie. "Gendered and racialised discourses of national identity in Baz Luhrmann's Australia.” Journal of Australian Studies 34.1 (March 2010): 63-77. Print.

Izod, John. “Walkabout: A Wasted Journey?” Sight and Sound 49.2 (1980): 113-116. Print.

Kemp, Philip. “Australia.” Sight and Sound 19.2 (February 2009): 48. Print.

Larkins, Bob. Chips: The life and films of Chips Rafferty. South Melbourne: MacMillan, 1986. Print.

Luckinbeal, Chris. “Cinematic Landscapes.” Journal of Cultural Geography 23.1 (Fall/Winter 2005): 3-22. Print.

Molloy, Bruce. Before the Interval: Australian Mythology and Feature Films, 1930-1960. Brisbane: University of Queensland Press, 1990. Print.

Nowra, Louis. Walkabout. Sydney: Currency Press, 2003. Print.

The Overlanders. Dir. Harry Watt. Ealing Studios, 1946. VHS. 
Papson, Stephen. “Baz Luhrmann’s Australia: when excess isn’t parody.” Web. 21 October 2011. <http://www.ejumpcut.org/trialsite/papsonAustralia/index.html.>

Pike, Andrew. “Aboriginals in Australian Feature Films.” Meanjin 36.4 (December 1977): 592-599. Print.

“Quandongs.” Web. 15 March 2012.

<http://www.nullarbornet.com.au/themes/quandongs.html.>

Red River. Dir. Howard Hawks. Monterey Productions, 1947. VHS.

Samson and Delilah. Dir. Warwick Thornton. CAAMA Productions, 2009. Film.

Seddon, George. The Old Country: Australian Landscapes, Plants and People. New York: Cambridge University Press, 2005. Print.

Strange, Dorothy. "Walkabout... a 16-Week Safari through the Modern Dreamtime.” Walkabout August 1971: 8-15. Print.

Ten Canoes. Dir. Rolf de Heer and Peter Djiggir. Fandango Australia, 2006. DVD.

The Tree. Dir. Julie Bertuccelli. Paramount, 2010. DVD.

Turk, Rachel. “Great Expectations.” Insidefilm (if) 115 (November 2008): 22-26. Print.

Verhoeven, Deb. "The film I would like to make: in search of a cinema (1927-1970)." In

Sabine, James (ed.). A Century of Australian Cinema. Port Melbourne: William Heinemann, 1995: 130-153. Print.

Walkabout. Dir. Nicolas Roeg. Max L. Raab - Si Litvinoff Productions, 1971. DVD. 